Provided for non-commercial research and education use. Not for reproduction, distribution or commercial use.

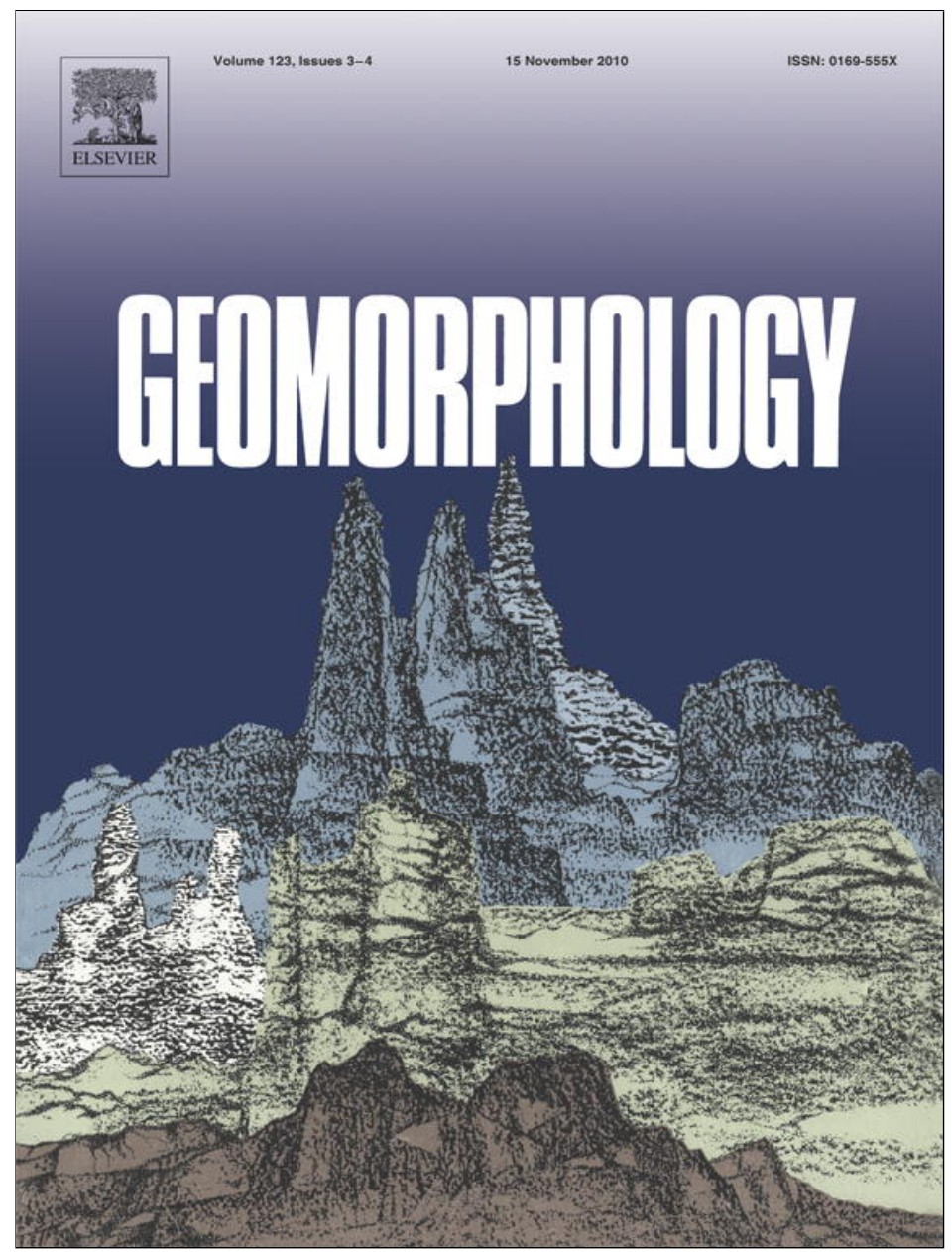

This article appeared in a journal published by Elsevier. The attached copy is furnished to the author for internal non-commercial research and education use, including for instruction at the authors institution and sharing with colleagues.

Other uses, including reproduction and distribution, or selling or licensing copies, or posting to personal, institutional or third party websites are prohibited.

In most cases authors are permitted to post their version of the article (e.g. in Word or Tex form) to their personal website or institutional repository. Authors requiring further information regarding Elsevier's archiving and manuscript policies are encouraged to visit:

http://www.elsevier.com/copyright 
Review

\title{
Geomorphology and Quaternary stratigraphy: The roles of morpho-, litho-, and allostratigraphy
}

\author{
P.D. Hughes * \\ Quaternary Environments and Geoarchaeology Research Group, Geography, School of Environment and Development, Arthur Lewis Building, \\ The University of Manchester, Manchester M13 9PL, United Kingdom
}

\section{A R T I C L E I N F O}

\section{Article history:}

Received 17 March 2010

Received in revised form 28 July 2010

Accepted 29 July 2010

Available online 11 August 2010

\section{Keywords:}

Allostratigraphy

Geomorphology

Lithostratigraphy

Morphostratigraphy

Quaternary science

\begin{abstract}
A B S T R A C T
The subdivision and ordering of Quaternary sediments and landforms is very often based on geomorphology Quaternary landforms such as moraines, river terraces, palaeoshorelines, and indeed any other landform, can be arranged and ordered in time based on their relative position in the landscape. Morphostratigraphy is the subdivision of sedimentary units primarily on the basis of surface form. Whilst surface form is often used as a criterion for separating sedimentary units, morphostratigraphy also usually incorporates lithological criteria to aid stratigraphical subdivision, and morpho- and lithostratigraphy are often interlinked in Quaternary science. However, another approach-allostratigraphy-has increasingly been applied to subdivide and order Quaternary sediment landforms. Allostratigraphy uses discontinuities to subdivide sedimentary successions. Allostratigraphy enables lateral variations in lithology to be included within the same stratigraphical unit. Furthermore, it enables lithologically similar sediments stacked on top of each other to be divided into separate units based on discontinuities. This paper examines the applications of morpho-, litho- and allostratigraphy to subdivide sediment-landform assemblages and critically reviews their role in Quaternary stratigraphy.
\end{abstract}

(c) 2010 Elsevier B.V. All rights reserved.

\section{Introduction}

Geomorphology is the study of landforms (and associated sediments) and the processes involved in their formation. Geomorphology is a major branch of Quaternary science, as processes operating during this interval are often expressed through landforms at the Earth's surface. This is especially true of processes that have operated during the last glacial cycle of the Late Pleistocene, although much older landforms are preserved too in a wide range of settings. Traditionally, the subdivision of Quaternary sediments based on geomorphological criteria has been served by morphostratigraphy, whilst the subdivision of Quaternary sediments based on lithological criteria has been served by lithostratigraphy (Hughes et al., 2005; Hughes, 2007). Given that geomorphology involves both the study of landforms and associated sediments, morphostratigraphy and lithostratigraphy are often applied together in Quaternary stratigraphy and form the basis for geomorphological approaches. However, alternative approaches exist too, and many papers simply describe their approach as "geomorphology" and subdivide sequences arbitrarily using ad hoc schemes with no reference to formal stratigraphical principles. An alternative formal approach is allostratigraphy which defines and identifies stratigraphical units by their bounding discontinuities (NACSN, 1983, pp. 865-867). Allostratigraphy has been widely applied to subdivide Quaternary sediments

\footnotetext{
* Tel.: + 441612757876.

E-mail address: philip.hughes@manchester.ac.uk.
}

based on geomorphology, because landforms inherently represent discontinuities at the Earth's surface, especially for alluvial, shoreline, and moraine sequences (e.g., Autin, 1992; Dahms, 2002; Marx et al., 2009). Furthermore, because the same geomorphological processes can produce lithologically similar sediments at different times at the same place, it has been argued that breaks or discontinuities in vertical successions best define the stratigraphical units. Räsänen et al. (2009) recently made this argument for lowland glacial deposits, although the same case could be made for a wide range of Quaternary sediments. The main aim of this paper is to examine the use of morpho- and lithostratigraphy toward the subdivision and ordering of Quaternary sediments and compare these approaches with allostratigraphy. The practical and philosophical problems associated with each will be discussed before an opinion is made on the merits of each and recommendations for future work.

\section{Stratigraphy and geomorphology in Quaternary science}

Stratigraphy is the science dealing with the description of all rock bodies (including sediments) and their organisation into distinctive, useful, mappable units based on their properties or attributes (Salvador, 1994, p. 137). Where the main property or attribute includes landform morphology, sediment characteristics, and sediment architecture, their organisation into distinctive, useful, mappable units can be achieved following three approaches: morphostratigraphy; lithostratigraphy, and; allostratigraphy. The principles of these are outlined below. 


\subsection{Morphostratigraphy}

Morphostratigraphy can be defined as the subdivision of sedimentary units based on surface form. Frye and Willman (1962) defined a morphostratigraphical unit as "a body of rock that is identified primarily from the surface form it displays". However, morphostratigraphical units often incorporate some element of lithological criteria (Bowen, 1978, p. 94). As a result, the spatial distribution of morphostratigraphical units is frequently presented using geomorphological maps, incorporating both morphological and lithological criteria. The term "morpholithostratigraphy" was used by Hughes et al. (2005) to describe the combined use of morpho- and lithostratigraphy in the subdivision and ordering of glacial sediments in mountain environments. Morpholithostratigraphy is widely employed in Quaternary science to subdivide a range of sedimentary successions and is a key component of geomorphology (Hughes, 2007).

\subsection{Lithostratigraphy}

Lithostratigraphy is the classification of rock units based on the observable lithological properties of the strata and their relative stratigraphical position (Salvador, 1994; Weerts and Westerhoff, 2007). Lithostratigraphical units are the basic units of geological mapping that conform to the Law of Superposition. Each formal lithostratigraphical unit should have a clear and precise definition or characterisation. A type section or a type locality is an essential requisite to all lithologically identified units. Salvador (1994, p. 26) defined type sections as "a specific interval or point in a specific sequence of rock strata and constitutes the standard for the definition and characterisation of the stratigraphic unit being defined," whilst the type locality refers to the geographical location of a type section.

Lithostratigraphical units should be defined and distinguished on the basis of sediment composition and texture including properties such as clast lithology, matrix composition, overall sorting, clast size, clast shape, clast roundness, and so on. Other attributes, such as sedimentary structures relating to geometry can also sometimes be useful, although must be characteristic of a lithological unit over wide areas and not merely local phenomena. Soil development may be an important characteristic of certain deposits and landforms. Pedostratigraphical units, are defined as "a buried, three-dimensional body of rock that consists of one or more pedological horizons" (NASCN, 1983, p. 864). Pedostratigraphical units are separate and of equal rank to lithostratigraphical units, but both share overlapping textural and compositional attributes, and may be useful as a marker horizon when applied in conjunction with the lithostratigraphy (Fig. 1).

The International Stratigraphic Guide states that when defining type sections the "geologic description covers lithology, thickness, paleontology, mineralogy, structure, geomorphic expression and other geologic features" (Salvador, 1994, p. 29). Application of this principle would imply that landform morphology, i.e., river terrace or moraine ridge, is a valid formal criterion for subdividing Quaternary, or indeed any other sediment record. In some instances, a constructional landform can also be equivalent to stratigraphical sediment architecture.

\subsection{Allostratigraphy}

An allostratigraphical unit is a body of sedimentary rock that is defined and identified by its bounding discontinuities (NACSN, 1983, pp. 865-867; Hughes, 2007). The fundamental units are the same as for lithostratigraphy but with the prefix allo-, i.e., allomember/ alloformation. Allostratigraphical units may be defined to distinguish between i) successions of lithologically similar deposits bounded by discontinuities; ii) contiguous, genetically related heterogeneous deposits bounded by discontinuities; and iii) geographically separated units separated by discontinuities. In the North American Stratigraphic
Code (NASCN, 1983), the bounding discontinuities are described as unconformities, disconformities, or the present-day land surface. In some instances, prolonged surface exposure may sometimes be recorded by soil development resulting in allostratigraphical boundaries being marked by soil horizons or palaeosols (Autin, 1992) (Fig. 1). Tracing a palaeosol along the upper boundary of a constructional palaeosurface provides evidence for recognition of an unconformity.

Allostratigraphical units are essentially the same as unconformitybounded units (cf., Chang, 1975) and are analogous to synthems as defined in the International Stratigraphic Guide (Salvador, 1994, p. 50). Allostratigraphy also represents a form of sequence stratigraphy. However, sequence stratigraphy tends to be applied at a larger scale and, unlike allostratigraphy, does not cover the special case of sediment or rock bodies of similar lithologies separated by discontinuities (Rawson et al., 2002, pp. 10-11). The latter is an important advantage of allostratigraphy because when using a lithostratigraphical approach, lithologically similar units separated by discontinuities would be classified as a single unit. Conversely, allostratigraphy also provides an objective method for the definition of sediment units that contain genetically related but heterogeneous sedimentary deposits. For example, Miall (1997, p. 12) argued that "allostratigraphic methods enable the erection of a sequence framework that avoids the cumbersome nature of lithostratigraphy, whereby lateral changes in facies within a unit of comparable age, require a change in name." A common goal of allostratigraphy is that, for homogeneous and heterogeneous sediment units, the defining discontinuities will have time-stratigraphical significance; and in this respect, the approach is similar to morphostratigraphy, which assumes time-stratigraphical significance for surface forms. Consequently, most Quaternary sedimentary successions that can be subdivided primarily on the basis of surface form can be subdivided using an allostratigraphical approach. In this respect, in addition to an erosional surface, a constructional surface may also be part of an allostratigraphical boundary.

\subsection{Informal approaches}

The subdivision and ordering of sediments and landforms in Quaternary Science is frequently done on an informal basis with no direct reference or acknowledgement of formal stratigraphical procedure. This is especially true where geomorphology is the main tool. Räsänen et al. (2009) argued that formal stratigraphical classifications are applied less regularly to Quaternary records, compared with preQuaternary geology, because the Quaternary research community is segregated into different schools of geology and geography. Nevertheless, all geomorphological approaches-whether done by geographers or geologists, or, informally or formally-employ criteria used in the definition of morpho-, litho-, and allostratigraphical units in order to subdivide Quaternary records.

\section{Application of morphostratigraphy, lithostratigraphy and allostratigraphy: examples from Quaternary records}

Morphostratigraphy, lithostratigraphy, and allostratigraphy have been used to subdivide and order a range of different Quaternary records. Examples from some of these records are explored below. The aim is not to provide an exhaustive catalogue of the research papers that have applied certain approaches, but rather to use the chosen Quaternary records to concisely illustrate the varied applications of the different stratigraphical approaches.

\subsection{Glacial sediments}

The interpretation of glacial landforms and associated sediments and the mapping of their relative position in the landscape often 


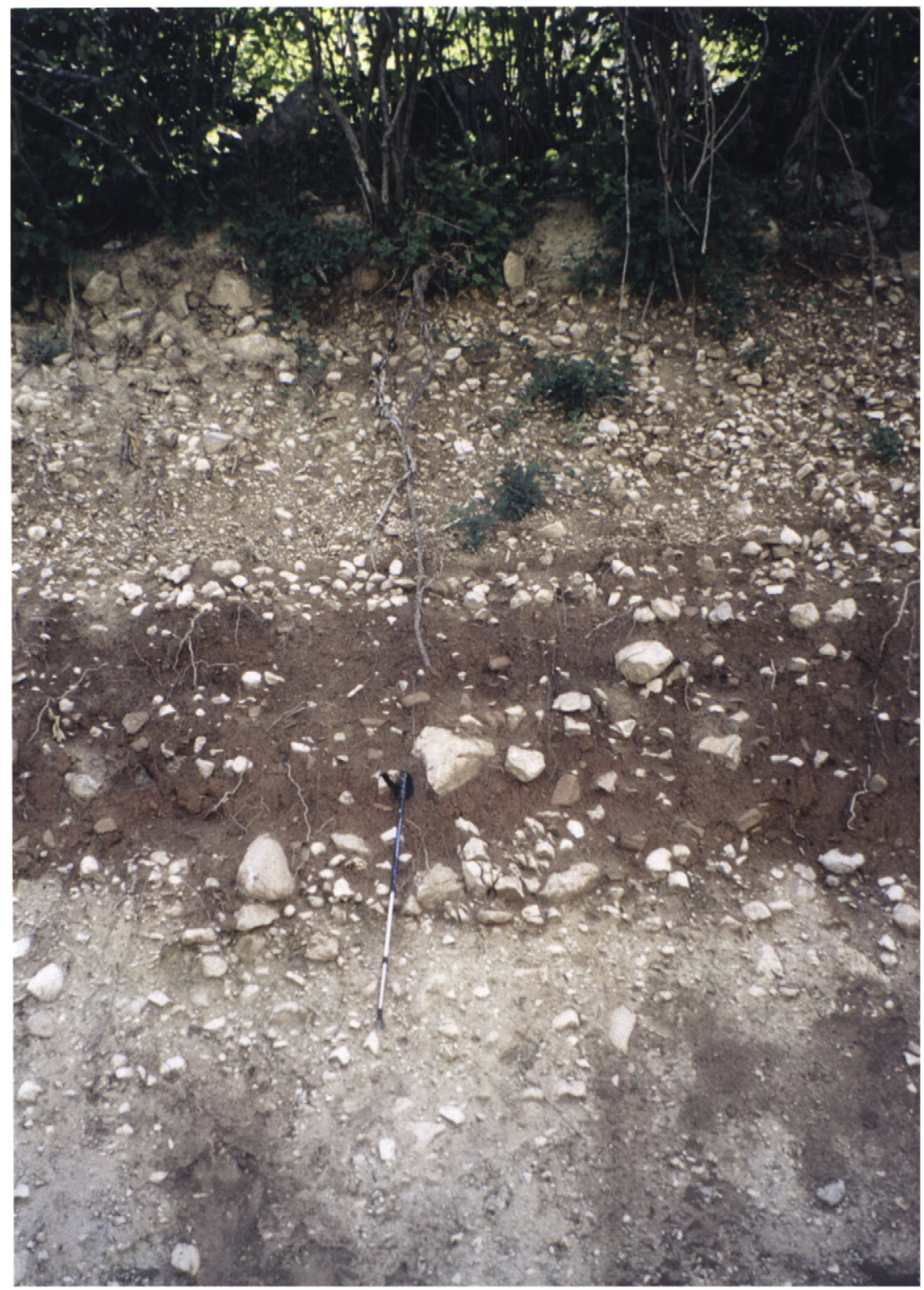

Fig. 1. Buried soil (palaeosol) formed on glacial deposits and overlain by colluvium in the Pindus Mountains, NW Greece. For scale, the walking stick is $1 \mathrm{~m}$ long. This soil is widespread in this area-both exposed at the surface and sometimes buried-and acts as a useful marker horizon and helps separate different sediment units in this area. Pedostratigraphy can be integrated within both litho- and allostratigraphical frameworks.

provides the basis for stratigraphical subdivision-especially, though not exclusively, in upland settings (e.g. Lukas, 2006) (Fig. 2). However, glacial deposits are often not morphologically expressed at the surface because of erosion or burial by more recent sediments (Fig. 3). In these circumstances, morphostratigraphy alone is limited in its power to subdivide the glacial record, and support is required from lithostratigraphical criteria (Pitkäranta, 2009). This is highlighted in papers by Owen et al. (1998) and Hughes et al. (2005, 2006b) who recognised the importance of a combined morphological and sedimentological approach to subdivide glacial deposits in mountain regions. The linkage of landforms and subsurface sediments and relating them genetically to process-landform studies underpins the "landsystems" approach in glacial geomorphology (Evans, 2003).

Allostratigraphical approaches have also been applied to subdivide and order glacial deposits (e.g., Dahms, 2002; James et al., 2002; Räsänen et al., 2009; Passchier et al., 2010). Glacial deposits represent successions of lithologically similar, contiguous, and geographically separated units-all separated by discontinuities. They appear, therefore, to have characteristics that are suited to an allostratigra- phical approach. Allostratigraphy is sometimes thought especially suitable for glacial successions because sediment units may appear indistinguishable on the basis of lithological criteria alone "due to the complexity and small-scale variation of the lithologic units in these deposits" (Räsänen et al., 2009, p. 4). Whether or not separate glacial units are rarely truly indistinguishable using lithological criteria is debatable, however, as numerous clast and matrix analyses (including macro- and micromorphology) can often detect subtle differences between units (e.g., Evans and Benn, 2004; Hughes et al., 2006a; see Fig. 4). This is true for many lithofacies and field mappability is the real test of the utility of a stratigraphical approach.

Räsänen et al. (2009) argued for the combined use of allo- and lithostratigraphy in a similar manner to Hughes et al. (2005) who argued for the integrated use of morpho- and lithostratigraphy. However, the two approaches vary in an important respect: in Räsänen et al. (2009, p. 9) the "allounits are given preference, and the lithostratigraphic units are subordinate to the allostratigraphy"; whilst in Hughes et al. (2005), morphological and lithological units are considered of equal importance at the outset. Whether or not 


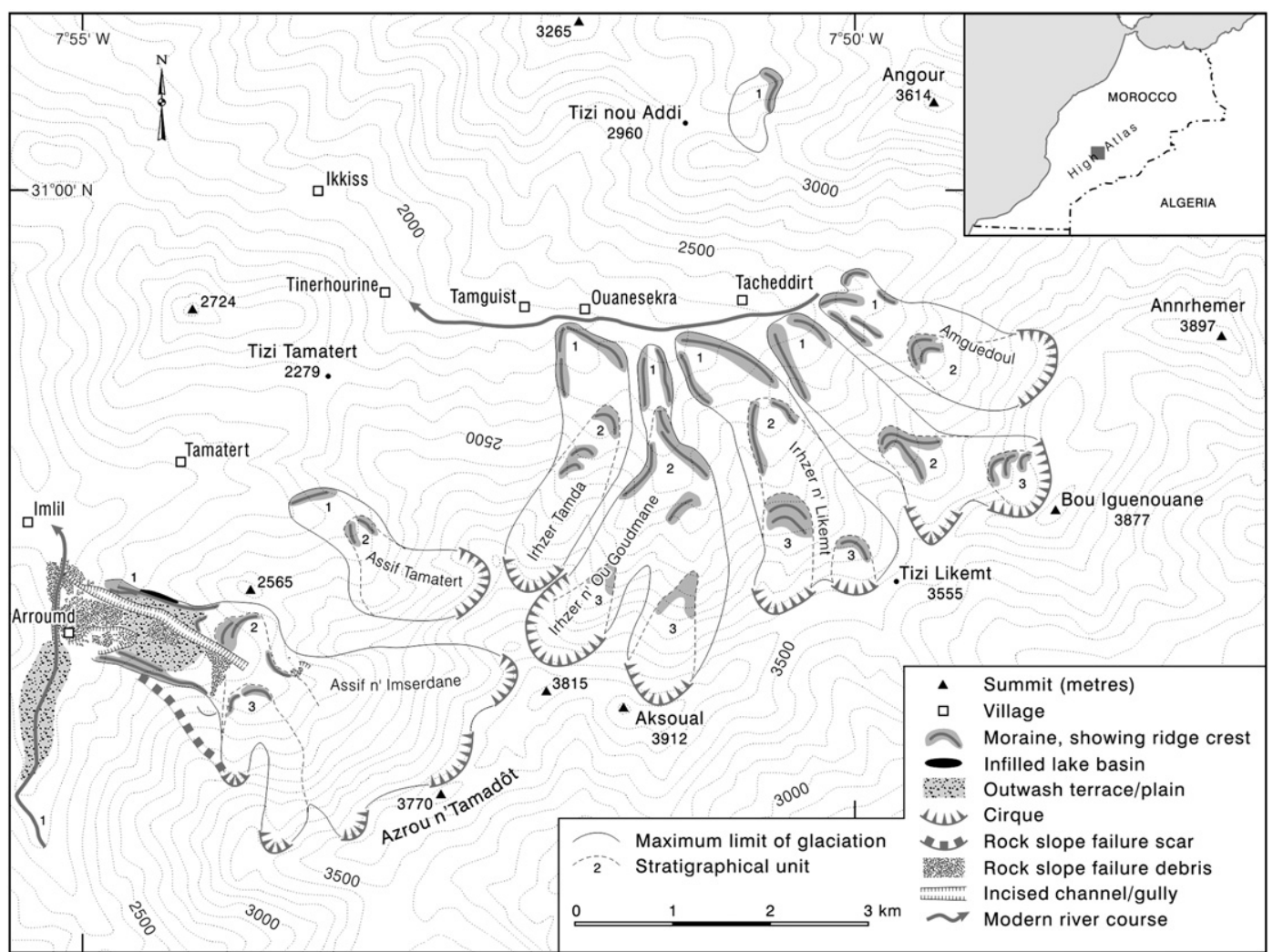

Fig. 2. Glacial geomorphological map of part of the High Atlas, Morocco. Moraines were separated on the basis of morphostratigraphical position and soil profile development. This stratigraphy was then tested using cosmogenic isotope analyses, which established the surface ages of moraines (Hughes et al., 2011).

morphological and lithological units become more important depends on which is the dominating criterion for sediment-landform subdivision. However, this is not to say that morpho- and lithostratigraphical units are mutually exclusive, only that emphasis should be placed on the criteria that are most discrimininating-which is often case dependent.

\subsection{Fluvial sediments}

Terraced fluvial successions represent a classic example where morphostratigraphy has been widely applied (e.g., Antoine et al., 2000; Sancho et al., 2008). Terrace surface age usually decreases with lower altitude. This is because phases of fluvial aggradation

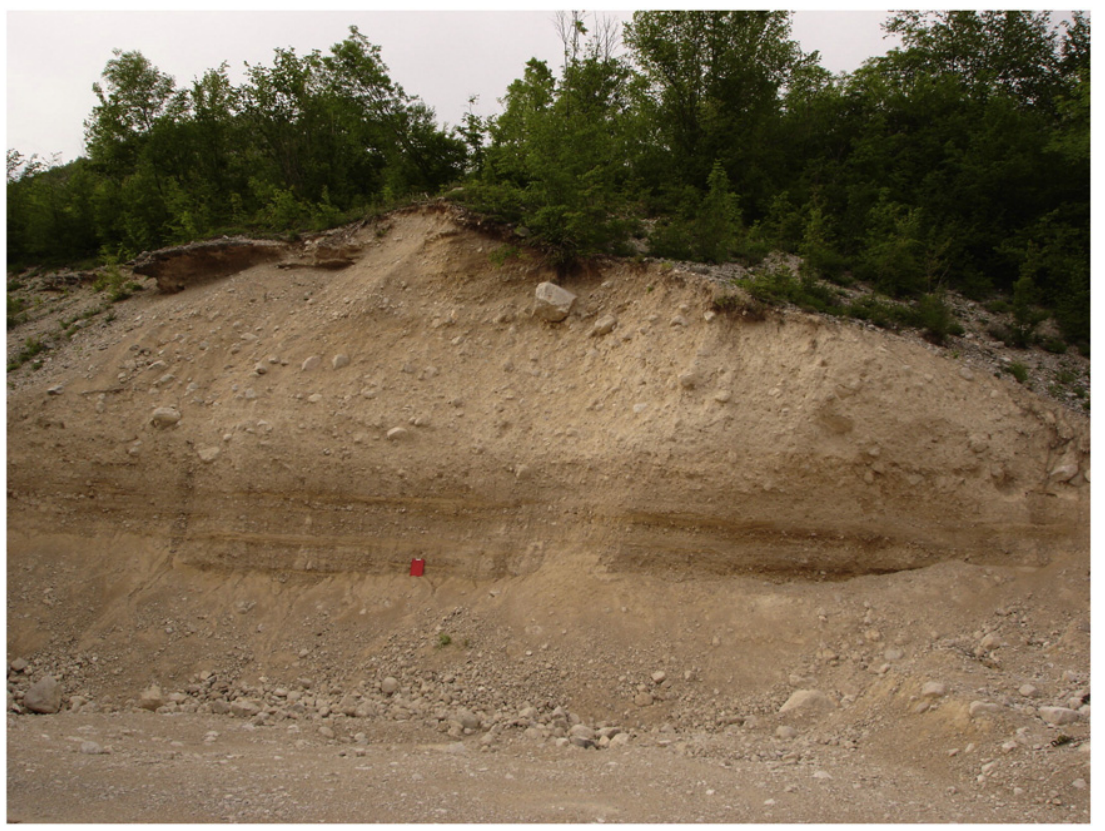

Fig. 3. Section on Mount Orjen, Montenegro. In this view, diamicton deposits can be seen overlying bedded sands and gravels. Just in view, the top of this section is comprised of cemented benches of sands and gravels overlying the diamicton deposits. The diamicton deposits are interpreted as till. The under- and overlying sands and gravels are interpreted as fluvial deposits, with the upper sands and gravels forming the surface of a terrace. In these circumstances, morphostratigraphy alone is limited in its power to subdivide the geomorphological record and support is required from lithostratigraphical criteria. 
(A)

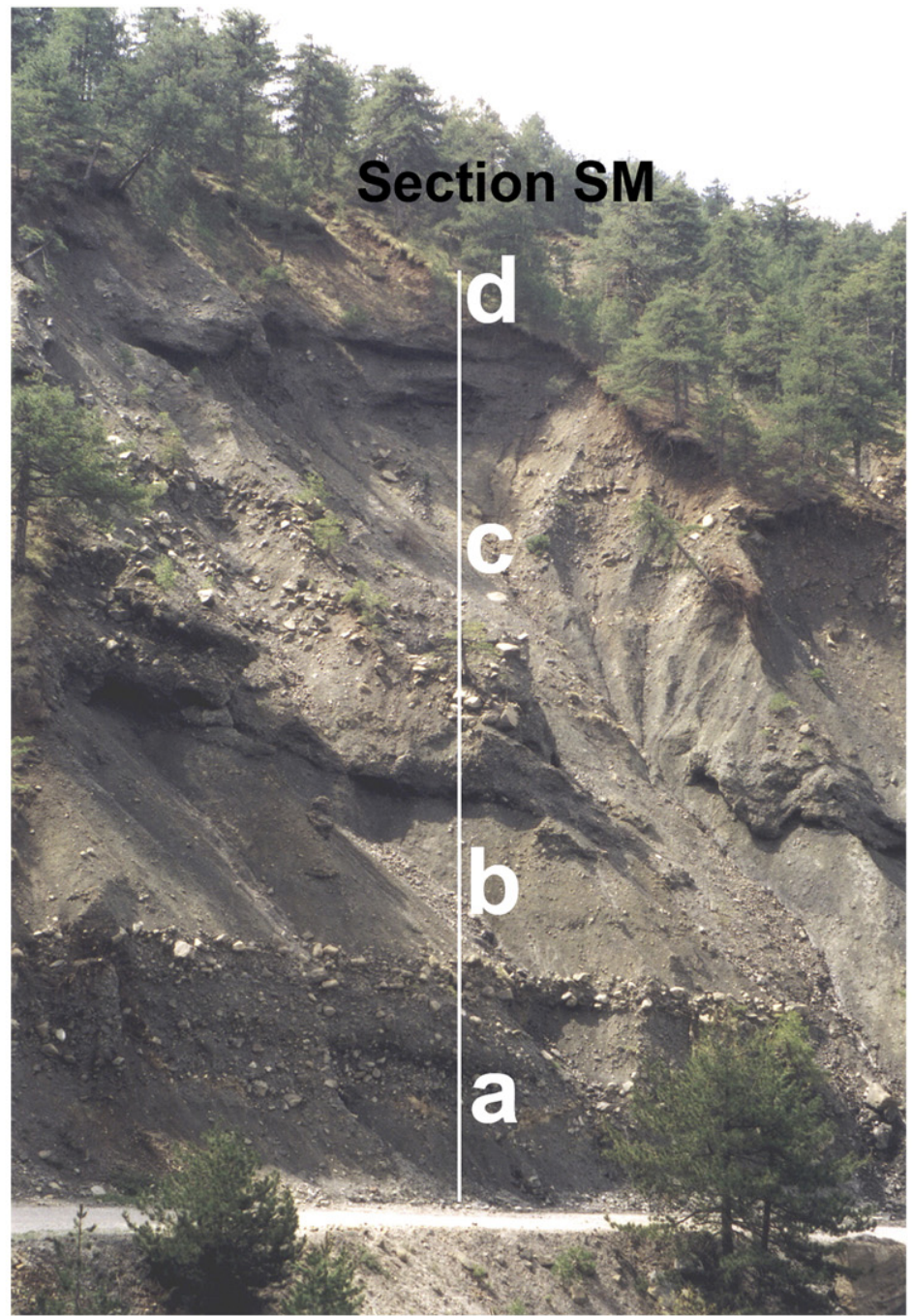

(B)

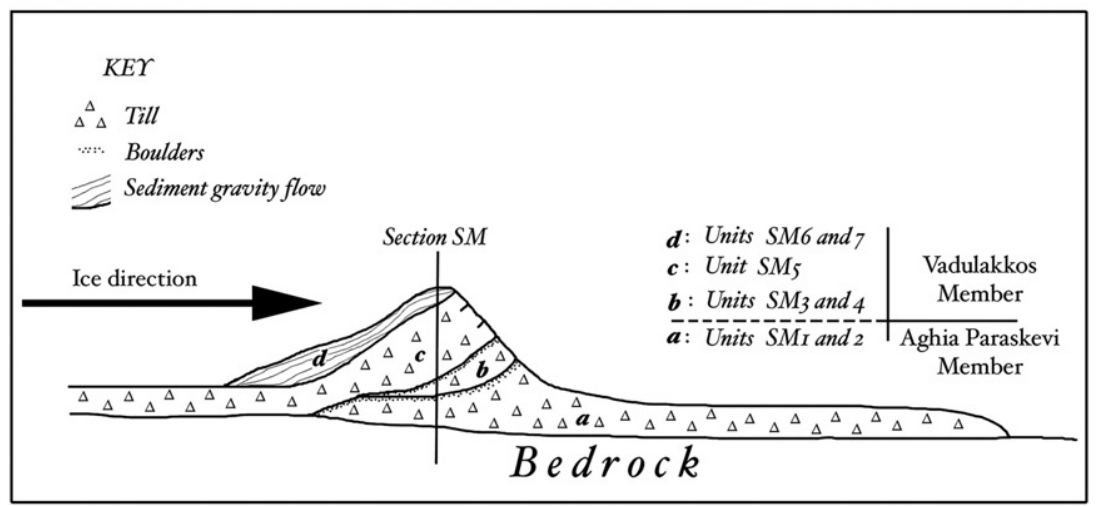

Fig. 4. A thick succession (>30 m) of multiple diamicton units on Mount Smolikas in northern Greece stacked and separated by discontinuities (A). These sediments are interpreted as till units and are expressed by a single clear moraine ridge at the surface and the sediment-landform assemblage represents a composite thrust moraine-see schematic sketch in (B) (Hughes et al., 2006b). Two of the diamicton units (units b and c) are separated by a mappable discontinuity present in glacial successions in other nearby valleys, but their lithofacies are similar. The two till units are the product of the same glacial event and the discontuinity is merely the product of an oscillating glacier front (Hughes et al., p.865). In this example, the use of discontinuities to subdivide and order sediments (allostratigraphy) will lead to the subdivision of sediment units closely related in both process and time (units b and c), leading to erroneous assumptions as to the relative age and relation of units. For this reason lithological criteria should be the primary stratigraphical tool.

interrupted by phases of incision often leads to a step-like profile in valley side fluvial sediments and a terraced morphology. Whilst the relative height of terrace surfaces reflects the relative ages of these surfaces, it conceals the complexities of the internal structure of terrace units. Thus, based on surface form alone, only a simplified history of fluvial activity can be inferred. A more comprehensive understanding of fluvial history can be achieved using a threedimensional alluvial stratigraphical approach utilising spatial variability in surface form and lithological characteristics (Mackey and Bridge, 1995). In his study of the Thames Valley, England, Gibbard $(1985,1994)$ utilised lithostratigraphy and biostratigraphy to subdivide and correlate fluvial sediments and recommended avoiding 
relying on morphostratigraphy (Gibbard, 1994, p. 9). In other studies, morphostratigraphy has played a more prominent role, although the relative importance of surface form above other properties, such as lithology, in subdividing fluvial successions depends on the scale of the river system concerned. Morphological mapping is usually done in conjunction with lithological evidence from sediment cores, test pits, or section exposures (e.g. Howard et al., 2004; Kasse et al., 2005). Morphological and lithological properties are also often combined with soil properties in order to separate and order alluvial units (Lewin et al., 1991; Woodward et al., 1994; Hamlin et al., 2000; Pope and Millington, 2000; Sancho et al., 2008; Woodward et al., 2008) (Fig. 5).

Fluvial successions are another classic case where allostratigraphy has also been widely applied (e.g., Autin, 1992; Blum et al., 1994; Autin, 1996; Straffin et al., 1999; Straffin, 2001; McCulloh et al., 2003; Sinha et al., 2005; Heinrich, 2006). In many river basins, alternating phases of fluvial deposition and incision produces terraced sedimentary units bounded by discontinuities. In a study of the Amite River (Louisiana, United States), Autin (1992) argued that allostratigraphy provides several benefits for studying floodplain stratigraphy. These include i) the criteria for the definition of alloformations conform with the formally defined stratigraphical procedures (NACSN, 1983); ii) alloformations are three-dimensional bodies of sediment whose deposits are genetically associated with a given meander belt created during a discrete time interval; iii) each alloformation contains a set of heterogeneous sedimentary deposits, and their evaluation can be related to a set of fluvial processes; and iv) this approach to geological mapping establishes a relative chronology for the units identified.

Autin (1992) concluded that if alternatives to the allostratigraphical approach are adopted, then interpretations of some floodplain fluvial sequences are limited. For example, Autin (1992) argued that whilst a morphostratigraphical approach may enable the association between constructional landscapes and sedimentary deposits to be inferred, a three-dimensional sediment body is not delineated. In addition, if sediment units are treated as lithostratigraphical units, the formations would reflect depositional processes and environments but would provide little or no information regarding valley chronology and evolution. However, later work in Mississippi Valley of
Louisiana has utilised a mixture of allostratigraphy, lithostratigraphy and pedostratigraphy depending on the specific problem being addressed (e.g. Autin, 1996; McCulloh et al., 2003; Heinrich, 2006).

\subsection{Lake sediments}

Changes in lake levels through time are often recorded by palaeoshorelines. Former shorelines record periods of lake level stability during high stands and provide important information regarding changing moisture conditions during the Quaternary. The morphology of former lake shorelines is often important when reconstructing past lake dimensions. For example, Schuster et al. (2005) identified palaeoshorelines of Holocene Lake Mega-Chad, in Africa, using satellite imagery to identify morphodynamic features of sedimentary systems. Most studies, however, utilise both morphological and lithological criteria identified in the field. Briggs et al. (2005) reconstructed Late Pleistocene and Late Holocene lake high stands in the Pyramid Lake sub-basin of Lake Lahontan, Nevada, USA, based on morphological evidence of palaeoshorelines and trenches cut through beach deposits. Similarly, in Mongolia, Komatsu et al. (2001) identified palaeoshorelines using both satellite/field-based morphological mapping and near-surface lithology.

Allostratigraphy has been employed by numerous researchers to understand the stratigraphy of lacustrine deposits, including at Lake Bonneville (Oviatt et al., 1994) and Lake Canyon (Pederson, 2000), both in the United States, and also at Lake Rotorua in New Zealand. Here, Marx et al. (2009) used allostratigraphy to subdivide and order lacustrine terraces (palaeoshorelines). They argued that "flights of terraces do not yield the stacking relationships useful in erecting a standard lithostratigraphy, but allostratigraphy provides an objective means of grouping heterogeneous lacustrine deposits that are nevertheless genetically related" (p. 352). At Lake Rotorua, bounding discontinuities are represented by pyroclastic deposits such as tephra marker horizons.

Sedimentation in lakes is largely continuous although variable in terms of rate and composition depending on the depth of the water column and environmental conditions within the water column and also at the surface. When erosion occurs this is often indicative of

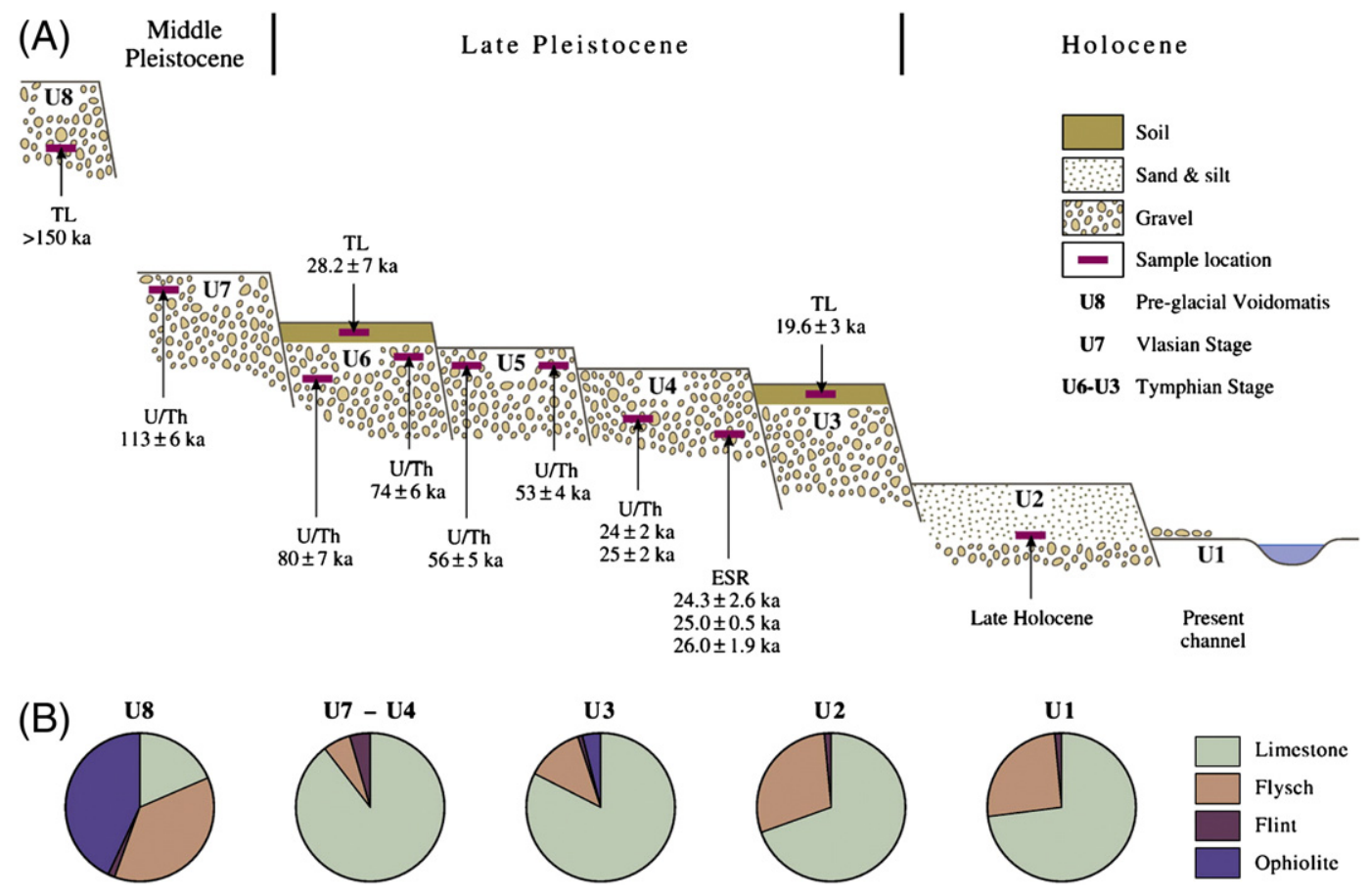

Fig. 5. A) Schematic diagram showing the Pleistocene and Holocene fluvial record in the Voidomatis River basin in northwest Greece (based on Lewin et al., 1991; Hamlin et al., 2000). B) The lithological composition of the gravels in the coarse-grained alluvial units (after Lewin et al., 1991). Diagram modified from Woodward et al. (2008). 


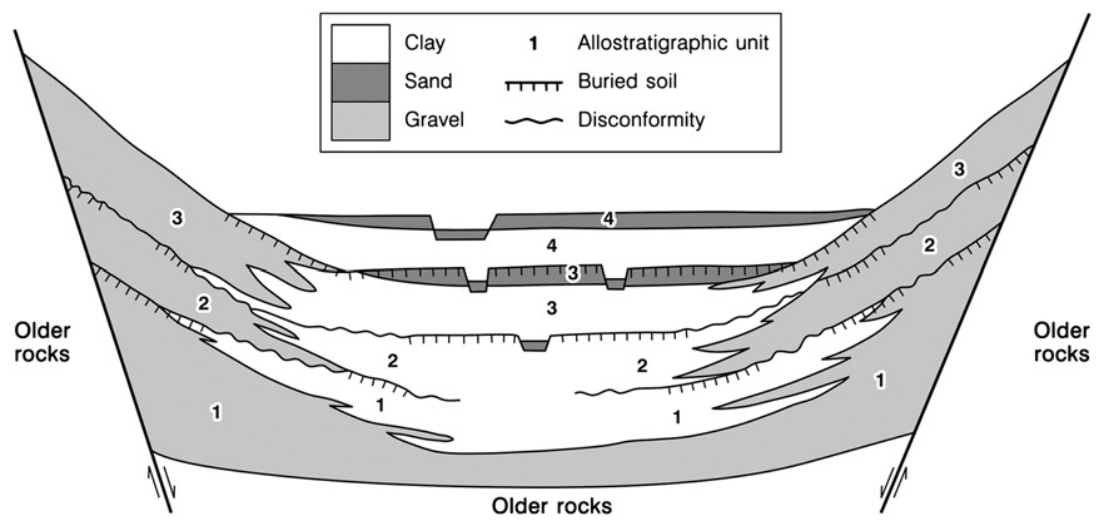

Fig. 6. An example of allostratigraphical classification in alluvial and lacustrine deposits in tectonic sedimentary basin (graben). Allostratigraphy enables sediment units to be defined on the basis of discontinuities and allows the grouping of genetically related but heterogeneous sediments within a single unit. From NACSN (1983). AAPG@1983. Redrawn by permission of the American Association of Petroleum Geologists.

major changes in the geomorphological state of the lake basin, such as major lake level regressions or subaqueous debris flows or landslides. Lateral variation in lithology between gravel and clay deposits will reflect position in the basin, and vertical variation in lithology may reflect changes in lake level. An allostratigraphical approach enables genetically related heterogeneous deposits (such as alluvial gravels and lacustrine clays within a basin) to be grouped within a single stratigraphical unit, as the subdivision of sediment units relies on the presence of a discontinuity (Fig. 6). In contrast, in a lithostratigraphical approach, gravel and clay deposits would be divided into separate stratigraphical units. However, the value of the different approaches depends whether researchers are interested in the processes leading to the discontinuities or in reconstructing gradual changes in environmental conditions within the basin over time. Allostratigraphy is clearly better for the former (Fig. 6) and lithostratigraphy for the latter (Fig. 7), although a combined approach may be useful too. Thus, sometimes an integrated approach using allo- and lithostratigraphy, in a similar manner recommended by Räsänen et al. (2009) for glacial deposits, may be suitable for lacustrine sequences.

\section{Which approaches to use in geomorphology and Quaternary stratigraphy?}

The use of allostratigraphy in subdividing Quaternary sediments has been widely applied by North American workers for a range of sedimentary settings around the world (see references above). Several geological surveys in the United States, such as Louisiana (McCulloh et al., 2003; Heinrich, 2006), Idaho (Breckenridge et al., 2005) and other state Geological Surveys utilise allostratigraphy to subdivide Quaternary deposits. However, allostratigraphy is a fairly new concept, having first appeared only in 1983 in the stratigraphical code (NACSN, 1983). Elsewhere, allostratigraphical approaches have, until recently, been rarely applied in Quaternary stratigraphy where morpho- and especially lithostratigraphy has dominated. In the UK, for example, the British Geological Survey employs lithostratigraphy to subdivide the Quaternary stratigraphical record (e.g. McMillan et al., 2005).

Autin (1996) argued that lithological heterogeneity resulting from the deposition of alluvial, deltaic, and coastal deposits makes lithostratigraphical definitions difficult and impractical. However, Rawson et al. (2002, pp. 10-11), suggest that if superposed or contiguous deposits of similar composition can be distinguished from each other, then classifying them as separately named lithostratigraphical units is justifiable. In the examples of glacial and fluvial successions described above this may in fact be quite straightforward based on even quite subtle lithological criteria.
Räsänen et al. (2009) attempted to reconcile allostratigraphy and lithostratigraphy and to advocate a combined use of allostratigraphy and lithostratigraphy (CUAL). Their arguments were based on the perceived practical problems in implementing lithostratigraphy to subdivide and order glacial deposits in lowland Fennoscandinavia, although such problems are strongly disputed by Johnson et al.

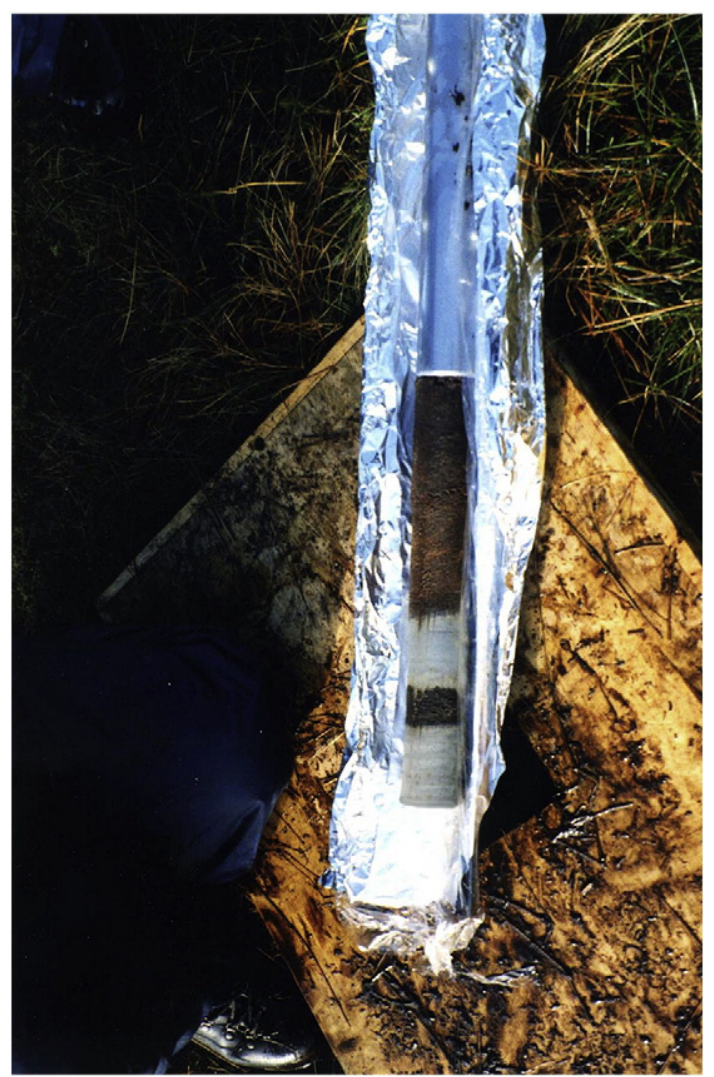

Fig. 7. Sediment core from a former lake basin (Ffridd-y-Fawnog) in North Wales. The lower tripartite minerogenic clay-organic silt-minerogenic clay sediment succession has been shown to correspond to major changes in the biostratigraphy associated with Late-glacial climatic fluctuations (Hughes, 2002). The boundaries between the three lower lithological units are gradational, whilst a hiatus exists between the upper clay and the overlying peat. This hiatus-corresponding approximately to the base of the Holocene-is mappable in lacustrine sediments across Wales and other areas of the British Isles. Allostratigraphy would identify just two units based on the discontinuity. Lithostratigraphy can identify at least four units, which are closely related to changes in biostratigraphy and associated climatostratigraphy. Furthermore, this lithostratigraphical tripartite succession is also mappable in lake sediments across Wales and other areas of the British Isles (Gray and Coxon, 1991). 
(2009). Räsänen et al. (2009, p. 9) concluded that lithostratigraphical, morpholithostratigraphical and allostratigraphical approaches are "in practice quite identical in the way in which they have been applied to Quaternary deposits". However, the main premise of their argument is "as that sequence stratigraphy has shown, unconformity-bounded units explain geologic history in a better way than lithostratigraphy" and, it is supposed here, morphostratigraphy too. Furthermore, Räsänen et al. (2009, p. 7) argued also that "morphogenetic" or "morphostratigraphic" approaches "may apply in areas of sediment cover derived from one glacial cycle, but it cannot apply to terrains with deposits from multiple glacial events."

The question of whether or not discontinuities in a vertical sedimentary succession should define the units has philosophical, as well as practical, implications. In terms of the former, building a stratigraphical framework based on what is missing rather than what is recorded in the stratigraphical column is questionable. Whilst unconformities define many major elements of the Earth's entire stratigraphical rock record (e.g. Cheney and Winter, 1995; Zorina et al., 2008), it is the rocks themselves that define the stratigraphical column. In many instances, the gaps in the stratigraphical record may represent not just a hiatus in process but erosion of a large part of the record too. Furthermore, erosion may occur rapidly and the use of discontinuities may in some circumstances lead to the subdivision of sediment units closely related in both process and time (or indeed the opposite), leading to difficulties in understanding the relative age and relation of units. The problem lies in properly defining the hierarchy of internal architecture, such as stratifications, scours, erosion surfaces, and unconformity (cf. Miall, 1985). When this can be satisfactorily defined then allostratigraphical principles can, in theory, still be applied. However, in practice, determining the hierarchy of internal architectural boundaries in Quaternary deposits is rarely straightforward. Sediment assemblages containing multiple erosion surfaces or unconformities, sometimes mappable over wide areas, may be formed within a relatively short space of time. Any hiatus may merely represent part of the wider landsystem-for example glacial and fluvial deposits that have formed close to an oscillating ice margin (e.g. Hughes et al., 2006b). Thus, it is preferable that discontinuities within Quaternary deposits should be viewed as merely sedimentary structures and that reliance should be made on lithological criteria to separate sediment units. An instance whereby discontinuities should be used as defining criteria should be reserved for surface forms, in which case the sediment unit can be defined using morphostratigraphical criteria.

Some have argued that morphostratigraphical units should have no formal stratigraphical status and that they should not be applied with any formal stratigraphical implication (e.g., Richmond, 1959; Bowen, 1978; Rawson et al., 2002, pp. 11-12). However, in practice morphostratigraphical units are rarely defined without using at least some lithological criteria (Bowen, 1978, p. 94). For example, glacial units may be recognised by lithological criteria incorporating a range of sedimentological characteristics (such as striated subrounded boulders and diamicton exposures) but separated by morphological criteria (such as moraine position). The fact that morphological and lithological criteria are often used to describe and subdivide glacial sediments led Hughes et al. (2005) to argue for the integration of morphostratigraphy within lithostratigraphy and the development of a formalised morpholithostratigraphical approach. In this scheme, morphostratigraphical units can be subdivided using formal lithostratigraphical terms, such as bed, member, formation, and group. Hughes et al. (2005) argued that the formalisation of morpholithostratigraphical approaches was useful for the development of robust terrestrial stratigraphical frameworks and for the systematic comparison of sediment units across wide areas, in not just glacial but a range of Quaternary sediments. Unfortunately, however, the past status of morphostratigraphy has inhibited the integration of geomorphological data within formal stratigraphical methods. Räsänen et al. (2009) claimed that this is symptomatic of the segregation of the Quaternary research community into geology and geography. They went on to note that morphostratigraphy is the favoured approach of the physical geographers (Räsänen et al., 2009, p. 7). This may be true, but their comments also reflect the limited consideration given to geomorphology by some geologists. Ultimately, the researcher's subject discipline, geography, geology, or otherwise, does not matter-the principles are the same. What differs is whether they are more concerned with sediment-rock successions or landforms. Both of these are narrow viewpoints and, hopefully, this paper has highlighted the fact that the two cannot be separated.

\section{Correlation}

\subsection{Mapping and correlating morpho-, litho- and allostratigraphical units}

Stratigraphy comprises two basic elements, sequence subdivision and correlation. Both are important for Quaternary studies, although the latter is the ultimate objective for scientists interested in regional palaeogeographical reconstructions, which in turn can be correlated with the major global climatic events that characterise the Quaternary (Morrison and Wright, 1965). Lithostratigraphical units can be correlated on the basis of lithological composition, texture and, in some cases, geometry. This has been successfully achieved for many different lithofacies and is a well-established approach (e.g. Gibbard, 1985). The main problems arise from the variabilities of scale and hierarchical subdivision of lithological units employed by different workers (Weerts and Westerhoff, 2007).

Establishing the time-equivalence of different morphostratigraphical units involves the correlation of surfaces. This is often aided by the integration of surface soil properties and pedostratigraphy, as noted earlier. Soil development effectively reflects the weathering of the landform surface and landforms of similar age using soils as a relative age tool (Harden, 1982; Birkeland, 1999). Surface landforms can also be correlated using a range of other criteria, such as morphostratigraphical position, altitude and degree of preservation. However, correlations using each of these approaches are fraught with difficulties and usually requires some geochronological control. Correlating on the basis of morphostratigraphical position essentially involves counting the number of stratigraphical units in a surface sequence and assuming correlative relations between different landform units in different areas. This can sometimes be intertwined with altitude. For example, in the case of fluvial systems the correlation of river terraces in a given valley is often achieved on the basis of the relative order of terraces and their respective altitudes (e.g. Bridgland, 1994)-a practice discouraged by Gibbard (1994, p. 9, see below). In the case of glaciated mountain systems, moraines may also be correlated between areas based on their relative position within cirque-valley systems. Altitudinal position can be important here too, although in the case of past glaciers it is the relative position of the reconstructed equilibrium line altitude of the palaeoglaciers that is important, rather than the altitudes of moraines (Benn and Lehmkuhl, 2000). However, problems occur when correlations are made over large distances because differing climate conditions can produce spatially- and temporally-complex glacier responses.

The main problem of correlation, for all types of morphostratigraphical units, is that some surfaces may be buried (or eroded) by later processes. In his study of the fluvial deposits of the Thames Valley in England, Gibbard (1994, p. 9) argued that morphostratigraphical approaches are "fraught with difficulties and often ignored the underlying deposits". Allostratigraphy offers some potential solutions since it can help build a 3-D view on landform surfaces and palaeosurfaces rather than the 2-D view offered by morphostratigraphy. However, there are still practical problems in correlating buried surfaces and unconformities to correlate sediments in the 
absence of a very high-resolution array of boreholes, exposures or seismic profiles. A further problem involves interpreting the processes leading to unconformities. Even where unconformities are mappable over wide areas, the processes responsible for these may vary in both time and space, resulting in spatially diachronous hiatuses. These problems potentially hinder allostratigraphical approaches built on breaks in the sediment record.

A further problem hindering the correlation of surface landforms is related to the genetic interpretation of such features. Surface form alone frequently provides insufficient evidence for interpreting landform genesis, especially given the similar forms produced by a range of different processes (equifinality). Sediment analysis is integral to the interpretation of constructional geomorphological landforms and lithological criteria, in conjunction with morphological criteria, are fundamental components of geomorphological mapping.

\subsection{Correlating stratigraphical units with large-scale climatic events}

The Quaternary has long been subdivided on the basis of climatic changes represented in the sediment record (Gibbard, 2007). Räsänen et al. (2009, p. 4 and their Fig. 1) appear to suggest that allostratigraphical classifications are easier to correlate with global climate changes than other approaches, such as lithostratigraphy. However, Johnson et al. (2009, p. e15) strongly disputed the claim and cited evidence of over 30 till units in Minnesota associated with Marine Isotope Stage (MIS) 2 where "the unconformities separating these units are more likely the product of ice dynamics and have little bearing on regional climate forcing". Nevertheless, some precedents in morphostratigraphy may support Räsänen et al.'s argument. For example, different river terrace units around the Mediterranean have been correlated with events recorded in the marine isotope record (Macklin et al., 2002; Woodward et al., 2008). Similarly, moraine surfaces are also frequently correlated with the marine isotope record (e.g., Akçar et al., 2008; Sarıkaya et al., 2008)-although in the case of moraines, in these and many other studies, multiple recessional and readvance moraine crests can clearly form within a relatively short space of time. The same is true of other processes, such as fluctuating lake shorelines, landslides, avulsing river channels, etc. If hiatuses (including surfaces) are to provide a robust framework for correlating with regional climatic signals, then they must provide a robust framework for building geochronologies.

The geochronology of landforms can be ascertained using techniques that either date landform surfaces or techniques that date the sediments of which the landforms are composed. Establishing geochronologies for landforms can involve a range of approaches that usually provide minimum ages, directly or indirectly, for the landform surface. One of the most direct approaches involves the application of terrestrial cosmogenic nuclide analyses to determine surface exposure ages (Gosse and Phillips, 2001; Seong et al., 2009). Indirect approaches include U-series dating of secondary calcites cementing landforms or their surfaces [such as moraines (e.g., Hughes et al., 2006a, 2010; Woodward et al., 2004), or river terraces (e.g., Woodward et al., 2008), or pedogenic calcretes (Candy et al., 2005)] and also radiocarbon dating of organic deposits resting on landform surfaces [such as glacial lake sediments (e.g. González-Sampériz et al., 2006)]. All of these techniques provide minimum ages for the associated landforms and effectively provide geochronologies for hiatuses in the geomorphological record. Conversely, other approaches involve the direct dating of landform sediments themselves. Examples include optically stimulated luminescence dating of river terrace gravels (Briant and Bateman, 2009), glacial sediments (Puthusserry et al., 2006; Lewis et al., 2009), or dunes; U-series dating of uplifted coral reefs or surface travertine benches; or radiocarbon dating of organic material within landforms, such as organic material within river gravels (Tornqvist et al., 1996; Briant and Bateman, 2009) or moraines (Colhoun and Synge, 1980).
Whilst landform surfaces can be effectively dated, and so too subsurface sediments, buried hiatuses are more difficult to datesimply because there is absence of a rock or sediment record. Examples where it is possible include the $\mathrm{Ar} / \mathrm{Ar}$ dating of tephras that sometimes drape by buried landform surfaces (Marx et al., 2009), Useries dating of calcrete benches that sometimes correspond to the surfaces of a former floodplain (Woodward et al., 2008), or radiocarbon dating of organic material in buried channel infills in fluvial settings (Briant and Bateman, 2009). Buried soils (palaeosols) can also provide useful marker horizons (Fig. 1), and can sometimes be dated using U-series (pedogenic calcrete) or radiocarbon techniques. However, in all of these cases it is the sediment or soil unit rather than the hiatus that is being dated-even with tephras and soils, which could be considered as lithological or pedological units in themselves. Rare exceptions include the application of terrestrial cosmogenic nuclide analyses to buried sediments, which can provide details of former exposure history and thus can effectively directly date a hiatus (Granger and Smith, 2000).

\section{Conclusions}

Geomorphology involves the combined use of morphological and lithological criteria to subdivide and order landforms and associated sediments. Morphostratigraphy and lithostratigraphy therefore provide the basis for geomorphology. An alternative view identifies the geomorphological approach as compatible with allostratigraphy, which subdivides and orders sediment units based on bounding discontinuities. Allostratigraphy is increasingly used, especially for glacial, fluvial, and lacustrine records. Advocates of the use of allostratigraphy in Quaternary argue that it is favourable to utilise both breaks in the record and also lithological characteristics to separate Quaternary sediments. However, this can also be easily facilitated by maintaining just lithostratigraphy for buried sediments and combining morphostratigraphy and lithostratigraphy for surface landforms and associated sediments. This combination of morphoand lithostratigraphy provides the basis for geomorphological research.

\section{Acknowledgements}

I would like to thank W.J. Autin, P.L. Gibbard and an anonymous referee for very helpful comments on an earlier draft of this paper.

\section{References}

Akçar, N., Yavuz, V., Ivy-Ochs, S., Kubik, P.W., Vardar, M., Schlüchter, C., 2008. A case for a down wasting mountain glacier during Termination I, Verçenik Valley, NE Turkey. Journal of Quaternary Science 23, 273-285.

Antoine, P., Lautridou, J.P., Laurent, M., 2000. Long-term fluvial archives in NW France: response of the Seine and Somme Rivers to tectonic movements, climatic variations and sea-level changes. Geomorphology 33, 183-207.

Autin, W.J., 1992. Use of alloformations for definition of Holocene meander belts in the middle Amite River, southeastern Louisiana. Geological Society of America Bulletin $104,233-241$

Autin, W.J., 1996. Pleistocene stratigraphy in the southern Lower Mississippi Valley. Engineering Geology 45, 87-112.

Benn, D.I., Lehmkuhl, F., 2000. Mass balance and equilibrium-line altitudes of glaciers in high mountain environments. Quaternary International 65 (66), 15-29.

Birkeland, P.W., 1999. Soils and Geomorphology, 3rd Edition. Oxford University Press, New York.

Blum, M.D., Toomey, R.S., Valastro, S.J., 1994. Fluvial response to late Quaternary climatic and environmental change, Edwards Plateau, Texas. Palaeogeography, Palaeoclimatology, Palaeoecology 108, 1-21.

Bowen, D.Q., 1978. Quaternary Geology: a Stratigraphic Framework for Multidisciplinary Work. Pergamon Press, Oxford, New York. 221 pp.

Breckenridge, R.M., Othberg, K.L., Kauffman, J.D., 2005. Surficial Geologic Map of the Mica Bay Quadrangle, Kootenai County, Idaho. Idaho Geological Survey, Moscow, Idaho.

Briant, R.M., Bateman, M.D., 2009. Luminescence dating indicates radiocarbon age under-estimation in Late Pleistocene fluvial deposits from eastern England. Journal of Quaternary Science 24, 916-927.

Bridgland, D.R., 1994. Quaternary of the Thames. Geological Conservation Review Series, vol. 7. Chapman and Hall, London. 440 pp. 
Briggs, R.W., Wesnousky, S.G., Adams, K.D., 2005. Late Pleistocene and late Holocene lake highstands in the Pyramid Lake subbasin of Lake Lahontan, Nevada, USA. Quaternary Research 64, 257-263.

Candy, I., Black, S., Sellwood, B., 2005. U-series isochron dating of immature and mature calcretes as a basis for constructing Quaternary landform chronologies for the Sorbas basin, southeast Spain. Quaternary Research 64, 100-111.

Chang, K.H., 1975. Unconformity-bounded stratigraphic units. Geological Society of America Bulletin 86, 1544-1552.

Cheney, E.S., Winter, H.de.la., 1995. The late Archean to Mezoproterozoic major unconformity-bounded units of the Kaapvaal Province of southern Africa. Precambrian Research 74, 203-223.

Colhoun, E.A., Synge, F.M., 1980. The cirque moraines at Lough Nahanaghan, Co. Wicklow, Ireland. Proceedings of the Royal Irish Academy 80B, 25-45.

Dahms, D.E., 2002. Glacial stratigraphy of Stough Creek Basin, Wind River Range, Wyoming. Geomorphology 42, 59-83.

Evans, D.J.A. (Ed.), 2003. Glacial Landsystems. Arnold, London. 532 pp.

Evans, D.J.A., Benn, D.I., 2004. A Practical Guide to the Study of Glacial Sediments. Arnold, London.

Frye, J.C., Willman, H.B., 1962. Morphostratigraphic units in Pleistocene stratigraphy. American Association of Petroleum Petrologists Bulletin 46, 112-113.

Gibbard, P.L., 1985. The Pleistocene History of the Middle Thames Valley. Cambridge University Press, Cambridge. 155 pp.

Gibbard, P.L., 1994. The Pleistocene History of the Lower Thames Valley. Cambridge University Press, Cambridge. 229 pp.

Gibbard, P.L., 2007. Climatostratigraphy. In: Elias, S.A. (Ed.), Encyclopedia of Quaternary Science. Elsevier, Amsterdam, The Netherlands, pp. 2819-2825.

González-Sampériz, P., Valero-Garcés, B.L., Moreno, A., Jalut, G., García-Ruiz, J.M., MartíBono, C., Delgado-Huertas, A., Navas, A., Otto, T., Dedoubat, J.J., 2006. Climate variability in the Spanish Pyrenees during the last 30,000 yr revealed by the $\mathrm{El}$ Portalet sequence. Quaternary Research 66, 38-52.

Gosse, J.C., Phillips, F.M., 2001. Terrestrial in situ cosmogenic nuclides: theory and application. Quaternary Science Reviews 20, 1475-1560.

Granger, D.E., Smith, A.L., 2000. Dating buried sediments using radioactive decay and muogenic production of ${ }^{26} \mathrm{Al}$ and ${ }^{10} \mathrm{Be}$. Nuclear Instruments and Methods in Physics Research Section B: Beam Interactions with Materials and Atoms 172, 822-826.

Gray, J.M., Coxon, P., 1991. The Loch Lomond Stadial glaciation in Britain and Ireland. In: Ehlers, J., Gibbard, P.L., Rose, J. (Eds.), Glacial Deposits in Great Britain and Ireland. AA Balkema, Rotterdam. 580 pp.

Hamlin, R.H.B., Woodward, J.C., Black, S., Macklin, M.G., 2000. Sediment fingerprinting as a tool for interpreting long-term river activity: the Voidomatis basin, NW Greece. In: Foster, I.D.L. (Ed.), Tracers in Geomorphology. John Wiley and Sons, Chichester, pp. 473-501.

Harden, J.W., 1982. A quantitative index of soil development from field descriptions: examples from a chronosequence in central California. Geoderma 28, 1-28.

Heinrich, P.V., 2006. Pleistocene and Holocene Fluvial Systems of the Lower Pearl River Mississippi and Louisiana, USA. Gulf Coast Association of Geological Societies Transactions 56, 267-278.

Howard, A.J., Macklin, M.G., Bailey, D.W., Mills, S., Andreescu, R., 2004. Late-glacial and Holocene river development in the Teleorman Valley on the southern Romanian Plain. Journal of Quaternary Science 19, 271-280.

Hughes, P.D., 2002. Loch Lomond stadial glaciers in the Aran and Arenig Mountains, North Wales. Geological Journal 37, 9-15.

Hughes, P.D., 2007. Allostratigraphy/morphostratigraphy. In: Elias, S. (Ed.), Encyclopedia of Quaternary Sciences. Elsevier, Amsterdam, The Netherlands, pp. 2841-2846.

Hughes, P.D., Gibbard, P.L., Woodward, J.C., 2005. Quaternary glacial records in mountain regions: a formal stratigraphical approach. Episodes 28, 85-92.

Hughes, P.D., Woodward, J.C., Gibbard, P.L., Macklin, M.G., Gilmour, M.A., Smith, G.R 2006a. The glacial history of the Pindus Mountains, Greece. Journal of Geology 114 413-434.

Hughes, P.D., Gibbard, P.L., Woodward, J.C., 2006b. Middle Pleistocene glacier behaviou in the Mediterranean: sedimentological evidence from the Pindus Mountains, Greece. Journal of the Geological Society, London 163, 857-867.

Hughes, P.D., Woodward, J.C., van Calsteren, P.C., Thomas, L.E., Adamson, K.R., 2010. Pleistocene ice caps on the coastal mountains of the Adriatic Sea. Quaternary Science Reviews. doi:10.1016/j.quascirev.2010.06.032.

Hughes, P.D., Fenton, C.R., Gibbard, P.L., 2011. Quaternary glaciations of the Atlas Mountains, North Africa. In: Ehlers, J., Gibbard, P.L, Hughes, P.D. (Eds.), Quaternary Glaciations-Extent and Chronology, Part IV-A Closer Look. Elsevier, Amsterdam, The Netherlands.

James, L.A., Harbor, J., Fabel, D., Dahms, D., Elmore, D., 2002. Late Pleistocene (2) northwestern Sierra Nevada, California. Quaternary Research 57, 409-419.

Johnson, M.D., Jennings, C., Hobbs, H., 2009. Lithostratigraphy for Quaternary glacial deposits: "If it ain't broke, don't fix it!". GSA Today 19, e15-e16. doi:10.1130/GSATG52C

Kasse, C., Hoek, W.Z., Bohncke, J.P., Konert, M., Weijers, W.H., Casse, M.L., Van der Zee, R.M., 2005. Late Glacial fluvial response of the Niers-Rhine (western Germany) to climate and vegetation change. Journal of Quaternary Science 20, 377-394.

Komatsu, G., Brantingham, P.J., Olsen, J.W., Baker, V.R., 2001. Paleoshoreline geomorphology of Böön Tsagaan Nuur, Tsagaan Nuur and Orog Nuur: the valley of the Lakes, Mongolia. Geomorphology 39, 83-98.

Lewin, J., Macklin, M.G., Woodward, J.C., 1991. Late Quaternary fluvial sedimentation in the Voidomatis Basin, Epirus, northwest Greece. Quaternary Research 35, 103-115.

Lewis, C.J., McDonald, E.V., Sancho, C., Luis Peña, J., Rhodes, E.J., 2009. Climatic implications of correlated Upper Pleistocene glacial and fluvial deposits on the Cinca and Gállego Rivers (NE Spain) based on OSL dating and soil stratigraphy. Global and Planetary Change 67, 141-152.
Lukas, S., 2006. Morphostratigraphic priciples in glacier reconstruction - a perspective from the British Younger Dryas. Progress in Physical Geography 30 719-736.

Mackey, S.D., Bridge, J.S., 1995. Three-dimensional model of alluvial stratigraphy: theory and application. Journal of Sedimentary Research B65, 7-31.

Macklin, M.G., Fuller, I.C., Lewin, J., Maas, G.S., Passmore, D.G., Rose, J., Woodward, J.C. Black, S., Hamlin, R.H.B., Rowan, J.S., 2002. Correlation of fluvial sequences in the Mediterranean basin over the last $200 \mathrm{ka}$ and their relationship to climate change. Quaternary Science Reviews 21, 1633-1641.

Marx, R., White, J.D.L., Manville, V., 2009. Sedimentology and allostratigraphy of post$240 \mathrm{ka}$ to pre-26.5 ka lacustrine terraces at intracaldera Lake Rotorua, Taupo Volcanic Zone, New Zealand. Sedimentary Geology 220, 349-362.

McCulloh, R.P., Heinrich, P.V., Snead, J.I., 2003. Geology of the Ville Platte Quadrangle Louisiana. To Accompany the Ville Platee $30 \times 60$ Minute Geologic Quadrangle. Louisiana Geological Survey, Geological Pamplet No. 14. Lousiana State University, Baton Rouge. 11 pp.

McMillan, A.A., Hamblin, R.J.O., Merritt, J.W., 2005. An overview of the lithostratigraphical framework for the Quaternary and Neogene deposits of Great Britain (onshore)British Geological Survey Research Report, RR/04/04, 38 pp. http://nora. nerc.ac.uk/3241/1/RR04004.pdf2005.

Miall, A.D., 1985. Architectural elements and bounding surfaces: a new method of facies analysis applied to fluvial deposits. Earth Science Reviews 22, 261-308.

Miall, A.D., 1997. The Geology of Stratigraphic Sequences. Springer-Verlag, Berlin.

Morrison, R.B., Wright, H.E. (Eds.), 1965. Means of Correlation of Quaternary Successions. : Proceedings, VII Congress, International Association for Quaternary Research, Volume 8. University of Utah Press, Salt Lake City. 631 pp.

North American Commission on Stratigraphic Nomenclature (NACSN), 1983. North American stratigraphic code. American Association of Petroleum Geologists, Bulletin 67, 841-875.

Oviatt, C.G., McCoy, W.D., Nash, W.P., 1994. Sequence stratigraphy of lacustrine deposits: a Quaternary example from the Bonneville basin, Utah. Geological Society of America Bulletin 106, 133-144.

Owen, L.A., Derbyshire, E., Fort, M., 1998. The Quaternary glacial history of the Himalaya. Quaternary Proceedings 6, 91-120.

Passchier, S., Laban, C., Mesdag, C.S., Rijsdijk, K.F., 2010. Subglacial bed conditions during Late Pleistocene glaciations and their impact on ice dynamics in the southern North Sea. Boreas 39, 633-647.

Pederson, J.L., 2000. Holocene paleolakes of Lake Canyon, Colorado Plateau: paleoclimate and landscape response from sedimentology and allostratigraphy. Geological Society of America Bulletin 112, 147-158.

Pitkäranta, R., 2009. Lithostratigraphy and age estimations of the Pleistocene erosiona remnants near the centre of the Scandinavian glaciations in western Finland. Quaternary Science Reviews 28, 166-180.

Pope, R.J.J., Millington, A.C., 2000. Unravelling the patterns of alluvial fan development using mineral magnetic analysis: examples from the Sparta Basin, Lakonia, southern Greece. Earth Surface Processes and Landforms 25, 601-615.

Puthusserry, T.J., Murray, A.S., Kjær, K.H., Funder, S., Larsen, E., 2006. Optically Stimulated Luminescence (OSL) dating of glacial sediments from Arctic Russiadepositional bleaching and methodological aspects. Boreas 35, 587-599.

Räsänen, M.E., Auir, J.M., Huitti, J.V., Klap, A.K., Virtasalo, J.J., 2009. A shift from lithostratigraphic to allostratigraphic classification of Quaternary glacial deposits. GSA Today $19,4-11$

Rawson, P.F., Allen, P.M., Brenchley, P.J., Cope, J.C.W., Gale, A.S., Evans, J.A., Gibbard, P.L. Gregory, F.J., Hailwood, E.A., Hesselbo, S.P., Knox, R.W.O'.B., Marshall, J.E.A., Oates, M., Riley, N.J., Smith, A.G., Trewin, N., Zalasiewicz, J.A., 2002. Stratigraphical Procedure. The Geological Society, London. 57 pp.

Richmond, G.M., 1959. Report of the Pleistocene Committee, American Commission on Stratigraphic Nomenclature. American Association of Petroleum Geologists Bulletin 43, 633-675.

Salvador, A. (Ed.), 1994. International Stratigraphic Guide: a Guide to Stratigraphic Classification, Terminology and Procedure, 2nd Edition. International Union of Geologic Sciences and The Geological Society of America, Boulder, CO. 214 pp.

Sancho, C., Peña, J.L., Muñoz, A., Benito, G., McDonald, E., Rhodes, E.J., Longares, L.A., 2008. Holocene alluvial morphopedosedimentary record and environmental changes in the Bardenas Reales Natural Park (NE Spain). Catena 73, 225-238.

Sarıkaya, M.A., Zreda, M., Çiner, A., Zweck, C., 2008. Cold and wet Last Glacial Maximum on Mount Sandıras, SW Turkey, inferred from cosmogenic dating and glacier modelling. Quaternary Science Reviews 27, 769-780.

Schuster, M., Roquin, C., Duringer, P., Brunet, M., Ciaugy, M., Fontugne, M., Mackaye, H.T. Vignaud, P., Ghienne, J.-F., 2005. Holocene lake Mega-Chad palaeoshorelines from space. Quaternary Science Reviews 24, 1821-1827.

Seong, Y.B., Owen, L.A., Yi, C., Finkel, R.C., 2009. Quaternary glaciation of Muztag Ata and Kongur Shan: evidence for glacier response to rapid climate changes throughout the late glacial and Holocene in westernmost Tibet. Bulletin of the Geological Society of America 121, 348-365.

Sinha, R. Gibling, M.R., Tandon, S.K. Jain, V. Dasgupta, A.S, 2005, Quaternary stratigraphy and sedimentology of the Korea section on the Betwa River, southern Gangetic Plains, Uttar Pradesh. Journal of the Geological Society of India 65, 441-450.

Straffin, E.C., 2001. Mapping with allostratigraphic frameworks: implications for understanding alluvial landscapes in southern Burgundy, France. In Bobrowsky, B. (Ed.), Geoenvironmental Mapping: Method, Theory and Practice. International Union of Geological Sciences (IUGS), Balkema, The Netherlands, pp. 147-167.

Straffin, E., Blum, M.D., Colls, A., Stokes, S., 1999. Alluvial stratigraphy of the Loire and Arroux Rivers (Burgundy, France). Quaternaire 10, 271-282. 
Tornqvist, T.E., Kidder, T.R., Autin, W.J., Borg, K. van der, de Jong, A.F.M., Klerks, C.J.W. Snijders, E.M.A., Storms, J.E.A., van Dam, R.L., Wiemann, M.C., 1996. A revised chronology for Mississippi River subdeltas. Science 273, 1693-1696.

Weerts, H.J.T., Westerhoff, W.E., 2007. Lithostratigraphy. In: Elias, S. (Ed.), Section 3: Quaternary Stratigraphy. Encyclopedia of Quaternary Sciences, Elsevier, Amsterdam, pp. 2826-2840.

Woodward, J.C., Macklin, M.G., Lewin, J., 1994. Pedogenic weathering and relative-age dating of Quaternary alluvial sediments in the Pindus Mountains of northwest Greece. In: Robinson, D.A., Williams, R.B.G. (Eds.), Rock Weathering and Landform Evolution. Wiley, Chichester, pp. 259-283.
Woodward, J.C., Macklin, M.G., Smith, G.R., 2004. Pleistocene glaciation in the Mountains of Greece. In: Ehlers, J., Gibbard, P.L. (Eds.), Quaternary GlaciationsExtent and Chronology. Part I: Europe. Elsevier, Amsterdam, pp. 155-173.

Woodward, J.C., Hamlin, R.H.B., Macklin, M.G., Hughes, P.D., Lewin, J., 2008. Glacial activity and catchment dynamics in northwest Greece: long-term river behaviour and the slackwater sediment record for the last glacial to interglacial transition. Geomorphology 101, 44-67.

Zorina, S.O., Dzyuba, O.S., Shurygin, B.N., Ruban, D.A., 2008. How global are the JurassicCretaceous unconformities? Terra Nova 20, 341-346. 